\title{
Acta
Biochimica
Polonica
}

Vol. 48 No. 1/2001

$113-119$

QUARTERLY

\section{Cation binding properties of calretinin, an EF-hand calcium-binding $\operatorname{protein}^{\star \star}$}

\author{
Patrick Groves $^{\bowtie}$ and Małgorzata Palczewska
}

\begin{abstract}
Laboratory of Calcium-Binding Proteins, Nencki Institute of Experimental Biology, Warszawa, Poland
\end{abstract}

Received: 1 October, 2000; revised: 15 January, 2001; accepted: 9 February, 2001

Key words: calcium binding protein, EF-hand, calretinin, S100 protein, metal binding; fluorescence

\begin{abstract}
Calretinin (CR) is a neuronal EF-hand protein previously characterized as a calcium (micromolar affinity) binding protein. CR-containing neurons are spared in some neurodegenerative diseases, although it is as yet unconfirmed how CR plays an active role in this protection. Higher levels of some metal cations (e.g. copper and zinc) are associated with these diseases. At the same time, metals such as terbium (NMR and fluorescence) cadmium (NMR) and manganese (EPR) serve as useful calcium analogues in the study of EF-hand proteins. We survey the binding of the above-mentioned metal cations that might affect the structure and function of CR. Competitive ${ }^{45} \mathrm{Ca}^{2+}$-overlay, competitive terbium fluorescence and intrinsic tryptophan fluorescence are used to detect the binding of metal cations to CR. Terbium and copper (half-maximal effect of $15 \mu \mathrm{M}$ ) bind to CR. Terbium has a similar or greater affinity for the calcium-binding sites of CR than calcium. Copper quenches the fluorescence of terbium-bound CR, and CR tryptophan residues and competes weakly for ${ }^{45} \mathrm{Ca}^{2+}$-binding sites. Cadmium, magnesium, manganese and zinc bind less strongly (half-maximal effects above $0.1 \mathrm{mM}$ ). Therefore, only terbium appears to be a suitable analytical calcium analogue in further studies of CR. The principal conclusion of this work is that copper, in addition to calcium, might be a factor in the function of CR and a link between CR and neurodegenerative diseases.
\end{abstract}

Calretinin (CR) is a neuronal EF-hand $\mathrm{Ca}^{2+}{ }^{+}$-binding protein of undefined function [1, 2]. EF-hands are helix-loop-helix motifs where the loop potentially binds $\mathrm{Ca}^{2+}$. CR has six EF-hands and binds $4-5 \mathrm{Ca}^{2+}$ ions with micromolar affinity [3-6]. EF-hand proteins have two principal func- tions. They act as $\mathrm{Ca}^{2+}{ }^{2+}$ sensors (part of $\mathrm{Ca}^{2+}{ }^{2}$-regulated pathways induced by increases in intracellular $\left[\mathrm{Ca}^{2+}\right]$ ) and/or $\mathrm{Ca}^{2+}$-buffers (protecting cells from increases in intracellular $\left.\left[\mathrm{Ca}^{2+}\right]\right)$. Large bodies of evidence support both a buffer and sensor role for CR (see [7] for review). More recent

\footnotetext{
ॠ Presented at the International Conference on "Conformation of Peptides, Proteins and Nucleic Acids", Debrzyno, Poland, 2000.

This work was supported by a grant from the State Committee for Scientific Research (KBN, Poland) No. 6 P04B 01015.

${ }^{凶}$ Correspondence to Patrick Groves, Laboratory of Calcium-Binding Proteins, Nencki Institute of Experimental Biology,

L. Pasteura 3, 02-093 Warszawa, Poland; fax: (48 22) 822 5342; tel: (48 22) 659 3143; e-mail: patrick@nencki.gov.pl

Abbreviations: CR, rat calretinin; EPR, electron paramagnetic resonance spectroscopy; GST, glutathione-S-transferase; HME, half maximal effect.
} 
work has described CR as a calcium buffer/transporter that regulates other calcium sensors [8] and the interaction of CR with intermediate filaments of microtubules [9].

The S100 group of EF-hand proteins have wellcharacterized zinc-binding properties [10-13] in addition to their $\mathrm{Ca}^{2+}$-binding properties. $\mathrm{S} 100 \mathrm{~B}$ was recently shown to bind $\mathrm{Cu}^{2+}$ much more strongly than $\mathrm{Ca}^{2+}$ and protect engineered $E$. coli cells expressing S100B from cell-damaging copper insults [14, 15]. Parvalbumin, belonging to a different EF-hand sub-family, also binds $\mathrm{Cu}^{2+}$ [16]. $\mathrm{Cu}^{2+}$ is a metal implicated in Parkinson's disease [17] while a subset of CR-containing neurons are spared from the same disease [18]. The exact role of CR in neurons is unknown but factors other than $\mathrm{Ca}^{2+}$ could be involved. Only the $\mathrm{Ca}^{2+}$ and $\mathrm{Mg}^{2+}$ binding properties of $\mathrm{CR}$ have been reported to date [3-6]. It is appropriate to study the effect of other metal cations with respect to CR's role in disease.

The main disadvantage of calcium is that it has few observable properties, with the exception of the radioactive ${ }^{45} \mathrm{Ca}^{2+}$ isotope and the relatively insensitive ${ }^{43} \mathrm{Ca}^{2+}$ isotope for NMR. Therefore, several metals with observable properties have been used as calcium substitutes to study EF-hand proteins. $\mathrm{Tb}^{3+}$ is used as a calcium analogue in fluorescence and NMR studies [19, 20] - as are other lanthanides [21, 22], $\mathrm{Cd}^{2+}$ in NMR studies [23] and $\mathrm{Mn}^{2+}$ in EPR studies [24].

The metals used in our studies include $\mathrm{Ca}^{2+}$ and $\mathrm{Mg}^{2+}$ as references in addition to the metals mentioned above. Competitive ${ }^{45} \mathrm{Ca}^{2+}$-overlay, competitive $\mathrm{Tb}^{3+}$-fluorescence and intrinsic fluorescence techniques are used to gauge the competitiveness of the metals against $\mathrm{Ca}^{2+}$ for $\mathrm{CR}$. We find that $\mathrm{Tb}^{3+}$ and $\mathrm{Cu}^{2+}$ bind to $\mathrm{CR}$ with micromolar affinities while $\mathrm{Mg}^{2+}, \mathrm{Cd}^{2+}$ and $\mathrm{Mn}^{2+}$ bind in the millimolar range. $\mathrm{Tb}^{3+}$ is a suitable calcium analogue and $\mathrm{Cu}^{2+}$ might be physiologically important to CR's function.

\section{MATERIALS AND METHODS}

Protein expression, purification and sample preparation. Recombinant rat $\mathrm{CR}$ was initially prepared as a gluatathione-S-transferase (GST) fusion product from an $E$. coli expression system [25]. It was purified by glutathione-Sepharose and, after thrombin cleavage of CR from resin-bound GST, DEAE-Sepharose affinity chromatography, as described [25]. Desalting was achieved by extensive dialysis against $1 \mathrm{mM}$ EDTA plus $1 \mathrm{mM}$ EGTA followed by dialysis against Chelex-100 (BioRad) treated water and lyophilization. Chelex-100 treated $50 \mathrm{mM}$ sodium acetate, $100 \mathrm{mM} \mathrm{KCl}$, pH 5.5 buffer was used in all experiments. This buffer was chosen as several metals form hydrated oxides at higher $\mathrm{pH}$ and to avoid known metal chelators such as histidine, as used by Maruyama et al. [26] in the original ${ }^{45} \mathrm{Ca}^{2+}$-overlay experiments.

EGTA was found to be unsuitable for producing the in situ apo state of the protein as it not only binds $\mathrm{Ca}^{2+}$ but also some of the metals we are interested in, resulting in complicated competitive titration curves. CR has a strong affinity for $\mathrm{Ca}^{2+}$ (0.1-1.0 $\mu \mathrm{M})$ [26] and tryptophan fluorescence titrations with EGTA and $\mathrm{CaCl}_{2}$ [4] indicated that the $\mathrm{CR}$ samples were partly $\mathrm{Ca}^{2+}$-bound. For this reason, $\mathrm{Ca}^{2+}$ was added to first saturate the samples for intrinsic fluorescence experiments.

Competitive ${ }^{45} \mathrm{Ca}^{2+}$-overlay. $200 \mu$ l of protein stock solutions ( $5 \mu \mathrm{g} / \mathrm{ml}$ ) of proteins in $50 \mathrm{mM}$ sodium acetate, $100 \mathrm{mM} \mathrm{KCl}, \mathrm{pH} 5.5$ buffer, together with $100 \mu \mathrm{M}$ of competitive metal cations, were dotblotted (Biodot, BioRad) onto nitrocellulose preconditioned with modified buffer $(0.45 \mu \mathrm{m}$, BioRad). This gave $1.0 \mu \mathrm{g}$ applications of CR per dot. $10 \mu \mathrm{M}$ of the appropriate competing metal cations were present in the buffers of all steps. The dots were washed with $3 \times 200 \mu \mathrm{l}$ of metal supplemented buffer. Then, about $1 \mu \mathrm{M}$ of ${ }^{45} \mathrm{Ca}^{2+}$ (1.88 mCi/ml, $0.1 \mathrm{mgCa} / \mathrm{ml}$, AmershamPharmacia) was added in $5 \mathrm{ml}$ of metal supplemented buffer. The dots were incubated for 10 min on a rocking platform. $10 \mathrm{ml}$ of metal supplemented buffer was used to wash the dots (rocking platform, $10 \mathrm{~min}$ ) before air-drying. After drying, the blots were submitted for autoradiography on Kodak Film and developed. All steps were carried out at room temperature. Each competing metal was measured in triplicate and the results normalized to a reference ${ }^{45} \mathrm{Ca}^{2+}$-overlay blot in which 
no competing cations were added. Densitometry of the blots was assessed using a Fluor-S MultiImager system (BioRad) to obtain the level of ${ }^{45} \mathrm{Ca}^{2+}$ bound to $\mathrm{CR}$ in the presence of different metals. The density of three dots was measured for each competitive cation together with three dots without protein to serve as background readings. The densities were normalized to the measurement of ${ }^{45} \mathrm{Ca}^{2+}$-binding to $\mathrm{CR}$ in the absence of metals. Results are reported for one complete experiment; repeat experiments provided similar results.

Competitive $\mathbf{T b}^{\mathbf{3}^{+}}$fluorescence. These experiments were carried out in $2 \mathrm{ml}$ of $50 \mathrm{mM}$ sodium acetate, $100 \mathrm{mM} \mathrm{KCl,} \mathrm{pH} 5.5$ buffer at $37^{\circ} \mathrm{C} .10 \mu \mathrm{l}$ of a $\mathrm{CR}$ stock solution was added to a final $1 \mu \mathrm{M}$ concentration. After measuring the baseline, $10 \mu \mathrm{l}$ of a stock $\mathrm{TbCl}_{3}$ solution was added to a final, saturating concentration of $50 \mu \mathrm{M}$. The solution was continuously stirred using a cuvette stirrer bar. Small volumes of metal chloride solutions (Sigma and other sources, analytical grade or better) were titrated into the $\mathrm{CR} / \mathrm{TbCl}_{3}$ solutions using an electronic pipetteman (Biohit Proline). The $\mathrm{Tb}^{3+}$-fluorescence peak at $545 \mathrm{~nm}\left(\lambda_{\text {em }}\right.$ scanned between 530 and $560 \mathrm{~nm}$ ) was monitored during the experiment using $\lambda_{\mathrm{ex}}=286 \mathrm{~nm}, 1 \mathrm{~s}$ acquisition time and $0.5 \mathrm{~nm}$ acquisition steps. The baseline was defined from a scan of the buffer containing protein and the data was normalized to the scan of protein with added $\mathrm{Tb}^{3+}$. All data was processed with KaleidaGraph (Synergy Software).

Intrinsic tryptophan fluorescence. This experiment was carried out as for the $\mathrm{Tb}^{3+}$ experiments but in the absence of $\mathrm{TbCl}_{3}$. For these experiments, calcium was added to the sample at a level determined by trial titrations with EGTA and $\mathrm{CaCl}_{2}$ [4]. This was done to ensure that the observed fluorescence changes are due to added metal and not due to calcium contamination. The protein was excited at $280 \mathrm{~nm}$ and emission spectra recorded between 330 and $350 \mathrm{~nm} ; 4$ scans with $1 \mathrm{~nm}$ acquisition step and $1 \mathrm{~s}$ acquisition time were averaged for each titration point. All data was normalized to the fluorescence produced by the protein minus the baseline arising from the buffer alone. All data was processed with KaleidaGraph (Synergy Software).

\section{RESULTS}

Competitive ${ }^{45} \mathrm{Ca}^{2+}$-overlay identifies metals that compete directly with $\mathrm{Ca}^{2+}$

The ${ }^{45} \mathrm{Ca}^{2+}$-overlay results indicate that $\mathrm{Tb}^{3+}$ is the strongest competitor of ${ }^{45} \mathrm{Ca}^{2+}$-binding, Fig. 1, as it reduces the amount of bound ${ }^{45} \mathrm{Ca}^{2+}$ to a similar extent as 'cold' $\mathrm{Ca}^{2+}$. This indicates the suitability of $\mathrm{Tb}^{3+}$ as a reporter of CR structure in fluorescence experiments (below). $\mathrm{Cu}^{2+}$ produced an about $30 \%$ decrease in ${ }^{45} \mathrm{Ca}^{2+}$-bind-

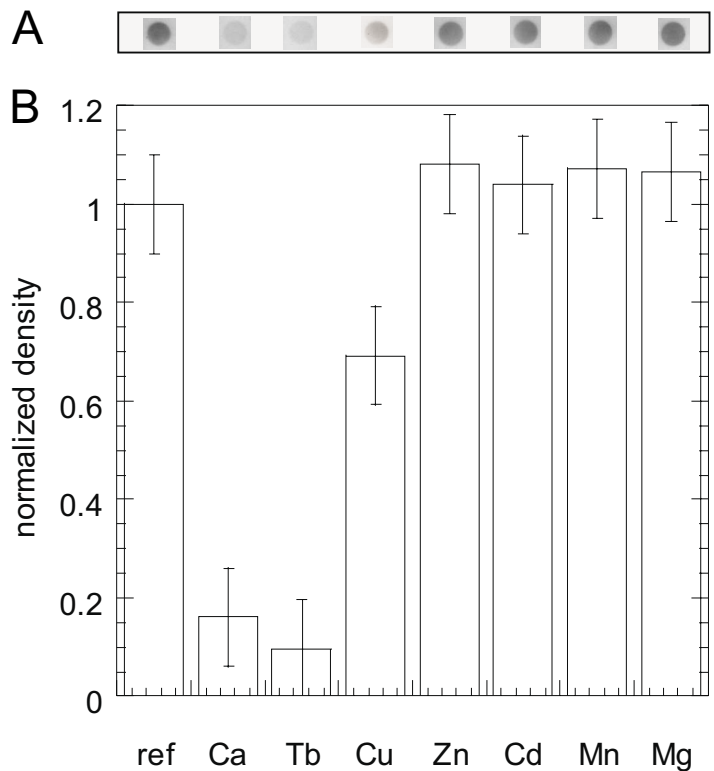

Figure 1. Results of competitive ${ }^{45} \mathrm{Ca}^{2+}$-overlay.

A. Autoradiogram of $1 \mu \mathrm{g}$ CR dots exposed to $1 \mu \mathrm{M}^{45} \mathrm{Ca}^{2+}$ plus $10 \mu \mathrm{M}$ competing metals indicated at the bottom of Fig. 1B. B. The density of three dots was averaged and the relevant background reading subtracted before normalization to ${ }^{45} \mathrm{Ca}^{2+}$ bound in the absence of any competing cation (ref). Competing metals are indicated at the bottom of the figure.

ing to $\mathrm{CR}$. Other metals have undetectable or moderate effects on ${ }^{45} \mathrm{Ca}^{2+}$ suggesting that they are poor direct competitors for the ${ }^{45} \mathrm{Ca}^{2+}$-binding sites.

\section{$\mathrm{Tb}^{3+}$ fluorescence}

$\mathrm{Ca}^{2+}$ does not completely remove $\mathrm{Tb}^{3+}$ from $\mathrm{CR}$, Fig. 2A. This reflects the concentration of $\mathrm{Tb}^{3+}$ and the fact that this metal probably has a stron- 
ger affinity than $\mathrm{Ca}^{2+}$ for the calcium-binding sites of CR, as found for the related calbindin $\mathrm{D}_{28 \mathrm{k}}$ [27]. However, this curve serves as a suitable reference to measure stronger or weaker effects of other metals. $\mathrm{Mg}^{2+}$ gives a mild response, Fig. 2A in agreement with previous data that $\mathrm{Mg}^{2+}$ binds to CR with a low affinity, if at all [5, 6].

The results indicate that $\mathrm{Cu}^{2+}$, at low concentrations, diminishes the $\mathrm{Tb}^{3+}$ signal more strongly

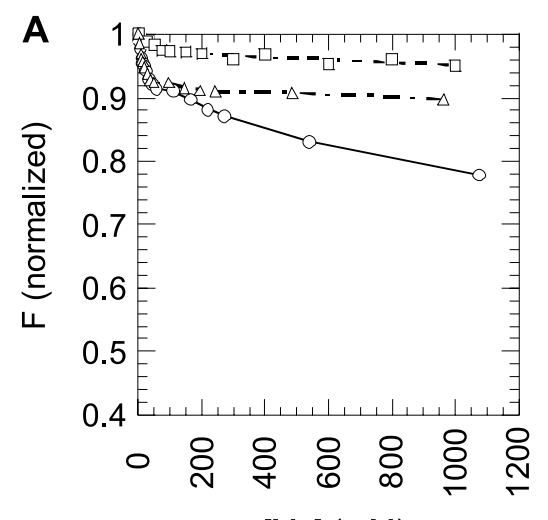

$[\mathrm{Mx}](\mu \mathrm{M})$

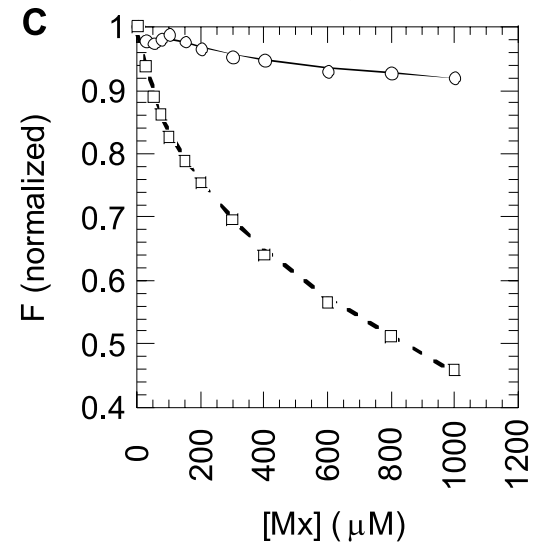

\section{Intrinsic tryptophan fluorescence}

No shifts in the emission maxima of CR (340 $\mathrm{nm}$ ) were noted for the binding of any of the competing metals. $\mathrm{Mg}^{2+}$-binding is undetected; the curve falls within the experimental error of the starting values, Fig. 3A. Fig. 3B shows that $\mathrm{Cu}^{2+}$ binds and quenches the CR tryptophan emission fluorescence. $\mathrm{Cu}^{2+}$ binds to $\mathrm{CR}$ with a similarly strong affinity as in the $\mathrm{Tb}^{3+}$-competition experi-

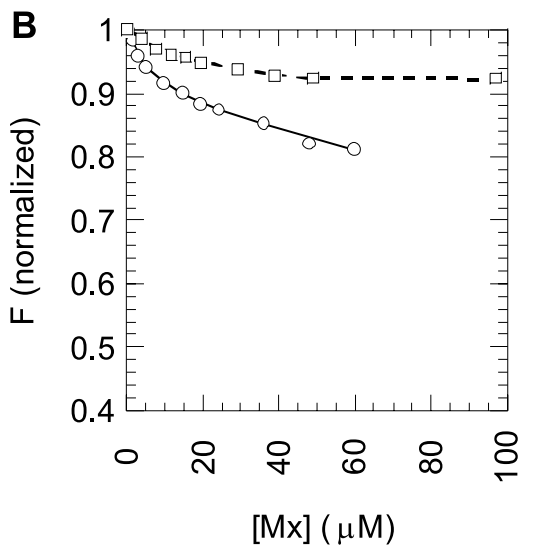

Figure 2. Normalized competitive $\mathrm{Tb}^{3+}$-fluorescence $(540-550 \mathrm{~nm})$ as a function of metal cation concentration $\left(\lambda_{\mathrm{ex}}=286 \mathrm{~nm}\right)$.

A. $\mathrm{Ca}^{2+}$ (circle and full line), $\mathrm{Mg}^{2+}$ (square and dotted line) and $\mathrm{Zn}^{2+}$ (triangle and dot-dash line); B. Cu ${ }^{2+}$ (circle and full line) and $\mathrm{Zn}^{2+}$ (square and dotted line); C. $\mathrm{Cd}^{2+}$ (circle and full line) and $\mathrm{Mn}^{2+}$ (square and dotted line). Average result of triplicate experiments, standard errors of individual points estimated as $\pm 5 \%$. Smoothed curves are fitted for data visualization.

than any other cation, Fig. $2 \mathrm{~B} . \mathrm{Zn}^{2+}$ also binds to CR at low concentrations (0-50 $\mu \mathrm{M})$, Fig. $2 \mathrm{~B}$, but the small maximum change in the $\mathrm{Tb}^{3+}$ signal is not much larger than that of $\mathrm{Mg}^{2+}$. The HME for $\mathrm{Cu}^{2+}$ is estimated as between 10 and $20 \mu \mathrm{M} . \mathrm{Cd}^{2+}$ behaves as modestly as $\mathrm{Mg}^{2+}$, with no significant changes in the $\mathrm{Tb}^{3+}$ signal, Fig. $2 \mathrm{C}$. $\mathrm{Mn}^{2+}$ binds to $\mathrm{CR}$ and strongly quenches the $\mathrm{Tb}^{3+}$ signal, Fig. $2 \mathrm{C}$, the half-maximal effect is about $100 \mu \mathrm{M}$. ment (10-20 $\mu \mathrm{M}$ HME). A change in binding slope occurs at concentrations of $\mathrm{Cu}^{2+}$ above 50 $\mu \mathrm{M} . \mathrm{Zn}^{2+}$ does not induce any large change in the intrinsic CR fluorescence, Fig. 3B. An about $100 \mu \mathrm{M}$ HME is observed for $\mathrm{Cd}^{2+}$, in contrast to the other fluorescence data, Fig. 3C. $\mathrm{Mn}^{2+}$-binding is complex, with two apparent binding events. The HMEs of $\mathrm{Mn}^{2+}$-binding are about 50 and about $600 \mu \mathrm{M}$, Fig. 3C. 


\section{DISCUSSION}

It is important to note that this study focuses on the $\mathrm{Ca}^{2+}$-binding sites of CR. A pH of 5.5 is suitable for these experiments and optimal to avoid the formation of insoluble metal hydroxides. Even so, an accurate estimate of the HME was not possible for $\mathrm{Cu}^{2+}$-binding effects as a visible turbidity of buffer solutions was noted at concentrations above $50 \mu \mathrm{M}$, indicating insolubility of the metal. The change in slope of Fig. 3B also occurs at about $50 \mu \mathrm{M}$ added $\mathrm{Cu}^{2+}$, providing confidence
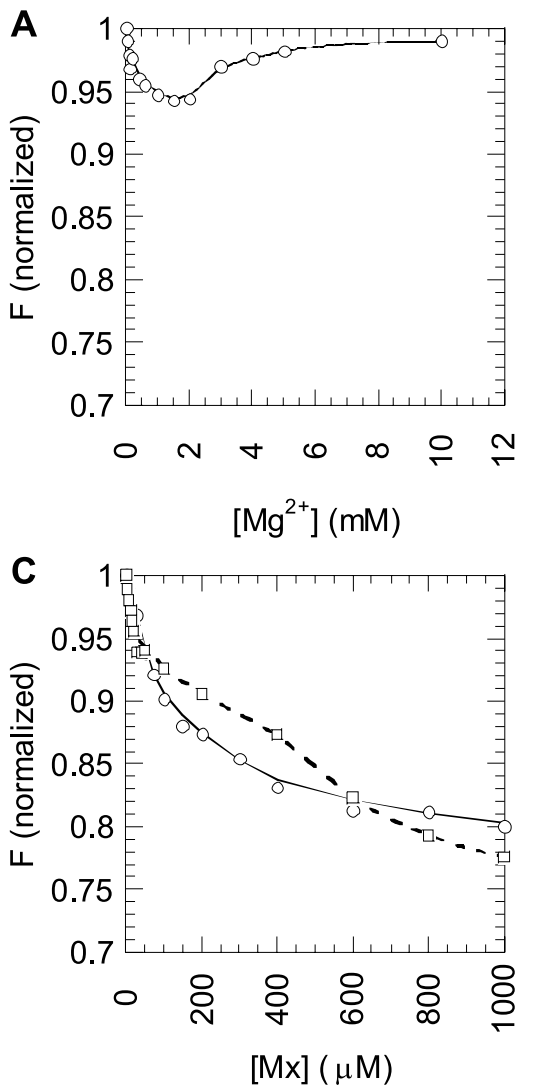

tryptophan residues to report on all metal-binding sites. Also, the methods used here are unlikely to be sensitive to all metals binding outside the $\mathrm{Ca}^{2+}$-binding sites.

The affinity of CR for $\mathrm{Mg}^{2+}$ has been established as $>1 \mathrm{mM}$ by two independent laboratories [5, 6]. $\mathrm{Mg}^{2+}$-binding sites are unobserved in the $\mathrm{Tb}^{3+}$ fluorescence data and $10 \mu \mathrm{M} \mathrm{Mg}^{2+}$ is too low a concentration to efficiently compete with ${ }^{45} \mathrm{Ca}^{2+}$ (Figs. 1 and 2). The changes in intrinsic fluorescence are $<10 \%$ and are considered insignificant. Therefore, our results agree with the published

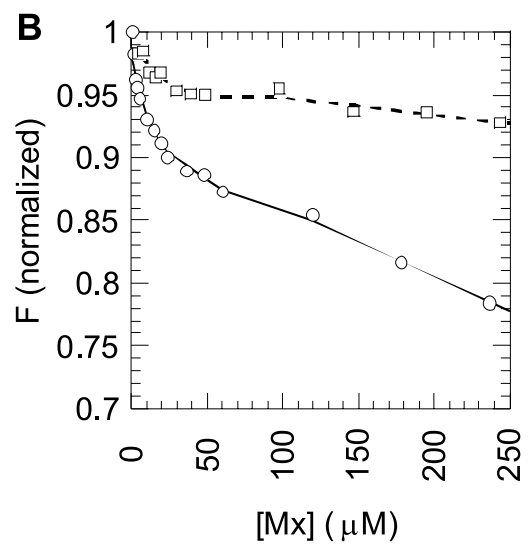

Figure 3. Normalized intrinsic tryptophan fluorescence $(330-350 \mathrm{~nm})$ as a function of metal cation concentration $\left(\lambda_{\text {ex }}=280 \mathrm{~nm}\right)$.

A. $\mathrm{Mg}^{2+}$; B. $\mathrm{Cu}^{2+}$ (circle and full line) and $\mathrm{Zn}^{2+}$ (square and dotted line); ${\mathrm{C} . \mathrm{Cd}^{2+}}^{2}$ (circle and full line) and $\mathrm{Mn}^{2+}$ (square and dotted line). Average result of triplicate experiments, standard errors of individual points estimated as $\pm 5 \%$. Smoothed curves are fitted for data visualization.

that binding effects in the $0-50 \mu \mathrm{M} \mathrm{Cu}{ }^{2+}$ range occur in the soluble range of $\mathrm{Cu}^{2+}$ in the acetate buffer. Our study surveys metals capable of binding to CR but not the accurate determination of binding affinities: CR has six EF-hands, an unknown number of other potential metal binding sites and the fluorescence methods rely on two data that $\mathrm{Mg}^{2+}$ does not bind strongly to CR (mM affinity for chick CR [6] and no affinity for human CR [5]) and does not induce a large conformational change.

Our results indicate which metals might be suitable as $\mathrm{Ca}^{2+}$-analogues in fluorescence, NMR and EPR experiments. The ${ }^{45} \mathrm{Ca}^{2+}$-overlay results 
clearly indicate a strong affinity of $\mathrm{CR}$ for $\mathrm{Tb}^{3+}$, Fig. 1. The affinity of other EF-hand proteins, including CR's close analogue - calbindin $\mathrm{D}_{28 \mathrm{k}}$, for $\mathrm{Tb}^{3+}$ and $\mathrm{Ca}^{2+}$ are often of a similar order [19, 27-29]. We use $\mathrm{Tb}^{3+}$-bound $\mathrm{CR}$ to observe the binding of several metals in fluorescence experiments. $\mathrm{Tb}^{3+}$ has also been used to obtain long-distance restraints in NMR structural studies of EF-hand proteins [20] and the knowledge that $\mathrm{CR}$ has a strong affinity for $\mathrm{Tb}^{3+}$ is of value to the NMR structure studies of truncated CR domains that are in progress. However, other lanthanides might better serve this purpose than $\mathrm{Tb}^{3+}[21,22,30]$. We conclude that a large excess of $\mathrm{Cd}^{2+}$ or $\mathrm{Mn}^{2+}$ would be required to saturate CR. Also, we cannot conclude from the set of presented data that $\mathrm{Mn}^{2+}$ binds only to the $\mathrm{Ca}^{2+}$-binding sites of CR.

$\mathrm{Cu}^{2+}$ strongly quenches the fluorescence of CR-bound $\mathrm{Tb}^{3+}$ and tryptophans in CR. A moderate level of ${ }^{45} \mathrm{Ca}^{2+}$-displacement is also detected. The simplest interpretation of this data is that $\mathrm{Cu}^{2+}$ displaces $\mathrm{Ca}^{2+}$ from the $\mathrm{Ca}^{2+}$-binding loops of $\mathrm{CR}$. However, it is possible that $\mathrm{Cu}^{2+}$-binds outside the $\mathrm{Ca}^{2+}$-binding sites, effects a conformational change and antagonizes $\mathrm{Ca}^{2+}$-binding to CR. The second interpretation corresponds to the $\mathrm{Cu}^{2+}$-binding properties of some $\mathrm{S} 100$ proteins and the lack of obvious $\mathrm{Cu}^{2+}$-binding ligands (histidine and cysteine) in the $\mathrm{Ca}^{2+}$-binding loops of $\mathrm{CR} . \mathrm{Zn}^{2+}$ and $\mathrm{Cu}^{2+}$ share similar chemistries and S100 binding properties. Therefore, $\mathrm{Zn}^{2+}$ could share the same binding site as $\mathrm{Cu}^{2+}$ but the employed methods are insensitive as $\mathrm{Zn}^{2+}$ does not have the same fluorescence quenching properties as $\mathrm{Cu}^{2+}$. The location of the $\mathrm{Cu}^{2+}$-binding sites are the subject of current investigation and preliminary data, utilizing more sensitive protocols, promise that both $\mathrm{Cu}^{2+}$ and $\mathrm{Zn}^{2+}$ bind to $\mathrm{CR}$ with a higher affinity at physiological $\mathrm{pH}$ than at $\mathrm{pH}$ 5.5. However, our main conclusion from the data presented here is that the $\mathrm{Cu}^{2+}$-binding HME of $15 \mu \mathrm{M}$ for $\mathrm{CR}$ might be relevant to CR's function.

To summarize, terbium, but not manganese or cadmium, is a suitable calcium analogue for further fluorescence and NMR studies of CR. Also, further research into the $\mathrm{Cu}^{2+}$-binding properties of $\mathrm{CR}$ at physiological $\mathrm{pH}$ is worthwhile with respect to the possible link this might have with CR's possible role in neurodegenerative disease.

We thank Dr. Jacek Kuźnicki for sharing his knowledge and experience with us and Mrs. Barbara Zarzycka for her technical assistance.

\section{R E F E R E N C E S}

1. Rogers, J.H. (1987) Calretinin: A gene for a novel calcium-binding protein expressed principally in neurons [published erratum appears in J. Cell Biol. (1990) 110, 1845]. J. Cell Biol. 105, 1343-1353.

2. Celio, M.R. (ed.) (1996) Guidebook to the Calcium-Binding Proteins. Sambrook \& Tooze with OUP (Oxford).

3. Cheung, W.T., Richards, D.E. \& Rogers, J.H. (1993) Calcium binding by chick calretinin and rat calbindin D28k synthesised in bacteria. Eur. J. Biochem. 215, 401-410.

4. Kuźnicki, J., Strauss, K.I. \& Jacobowitz, D.M. (1995) Conformational changes and calcium binding by calretinin and its recombinant fragments containing different sets of EF hand motifs. Biochemistry 34, 15389-15394.

5. Schwaller, B., Durussel, I., Jermann, D., Herrmann, B. \& Cox, J.A. (1997) Comparison of the $\mathrm{Ca}^{2+}$-binding properties of human recombinant calretinin-22k and calretinin. J. Biol. Chem. 272, 29663-29671.

6. Stevens, J. \& Rogers, J.H. (1997) Chick calretinin: Purification, composition, and metal binding activity of native and recombinant forms. Protein Expr. Purif. 9, 171-181.

7. Billing-Marczak, K. \& Kuźnicki, J. (1999) Calretinin-sensor or buffer-function still unclear. Pol. J. Pharmacol. 51, 173-178.

8. Edmonds, B., Reyes, R., Schwaller, B. \& Roberts, W.M. (2000) Calretinin modifies presynaptic calcium signaling in frog saccular hair cells. Nat. Neurosic. 3, 786-790.

9. Marilley, D. \& Schwaller, B. (2000) Association between the calcium-binding protein calretinin and cytoskeletal components in the human colon 
adenocarcinoma cell line WiDr. Exp. Cell Res. 259, $12-22$.

10. Baudier, J. \& Gerard, D. (1983) Ions binding to S100 proteins: Structural changes induced by calcium and zinc on S100a and S100b proteins. Biochemistry 22, 3360-3369.

11. Baudier, J., Glasser, N. \& Gerard, D. (1986) Ions binding to S100 proteins. I. Calcium- and zinc-binding properties of bovine brain $\mathrm{S} 100$ alpha alpha, S100a (alpha beta), and S100b (beta beta) protein: $\mathrm{Zn}^{2+}$ regulates $\mathrm{Ca}^{2+}$ binding on $\mathrm{S} 100$ b protein. J. Biol. Chem. 261, 8192-8203.

12. Filipek, A., Heizmann, C.W. \& Kuźnicki, J. (1990) Calcyclin is a calcium and zinc binding protein. FEBS Lett. 264, 263-266.

13. Heizmann, C.W. \& Cox, J.A. (1998) New perspectives on S100 proteins: A multi-functional $\mathrm{Ca}(2+)$, $\mathrm{Zn}\left(2^{+}\right)$- and $\mathrm{Cu}\left(2^{+}\right)$-binding protein family. Biometals 11, 383-397.

14. Nishikawa, T., Lee, I.S., Shiraishi, N., Ishikawa, T., Ohta, Y. \& Nishikimi, M. (1997) Identification of $\mathrm{S} 100 \mathrm{~b}$ protein as copper-binding protein and its suppression of copper-induced cell damage. J. Biol. Chem. 272, 23037-23041.

15. Shiraishi, N. \& Nishikimi, M. (1998) Suppression of copper-induced cellular damage by copper sequestration with S100b protein. Arch. Biochem. Biophys. 357, 225-230.

16. Permyakov, E.A., Kalinichenko, L.P., Derezhkov, V.Y., Antalik, M., Meinholtz, D.C. \& Berliner, L.J. (1992) Interaction of cupric ion with parvalbumin. Biophys. Chem. 42, 189-194.

17. Sayre, L.M., Perry, G. \& Smith, M.A. (1999) Redox metals and neurodegenerative disease. Curr. Opin. Chem. Biol. 3, 220-225.

18. Mouatt-Prigent, A., Agid, Y. \& Hirsch, E.C. (1994) Does the calcium binding protein calretinin protect dopaminergic neurons against degeneration in Parkinson's disease? Brain Res. 668, 62-70.

19. Chaudhuri, D., Horrocks, W.D., Jr., Amburgey, J.C. \& Weber, D.J. (1997) Characterization of lanthanide ion binding to the EF-hand protein S100 beta by luminescence spectroscopy. Biochemistry 36, 9674-9680.

20. Biekofsky, R.R., Muskett, F.W., Schmidt, J.M., Martin, S.R., Browne, J.P., Bayley, P.M. \& Feeney, J. (1999) NMR approaches for monitoring domain orientations in calcium-binding proteins in solution using partial replacement of $\mathrm{Ca}^{2+}$ by $\mathrm{Tb}^{3+}$. FEBS Lett. 460, 519-526.

21. Siedlecka, M., Goch, G., Ejchart, A., Sticht, H. \& Bierzyński, A. (1999) Alpha-helix nucleation by a calcium-binding peptide loop. Proc. Natl. Acad. Sci. U.S.A. 96, 903-908.

22. Bentrop, D., Bertini, I., Cremonini, M.A., Forsén, S., Luchinat, C. \& Malmendal, A. (1997) Solution structure of the paramagnetic complex of the $\mathrm{N}$-terminal domain of calmodulin with two $\mathrm{Ce}^{3+}$ ions by ${ }^{1} \mathrm{H}$ NMR. Biochemistry 36, 11605-11618.

23. Akke, M., Forsén, S. \& Chazin, W.J. (1995) Solution structure of $(\mathrm{Cd} 2+) 1$-calbindin D9k reveals details of the stepwise structural changes along the apo->(Ca2+)II1->(Ca2+)I,II2 binding pathway. J. Mol. Biol. 252, 102-121.

24. Rustandi, R.R., Drohat, A.C., Baldisseri, D.M., Wilder, P.T. \& Weber, D.J. (1998) The Ca(2+)-dependent interaction of $\mathrm{S} 100 \mathrm{~B}$ (beta beta) with a peptide derived from p53. Biochemistry 37, 19511960.

25. Strauss, K.I., Kuźnicki, J., Winsky, L. \& Jacobowitz, D.M. (1994) Expression and rapid purification of recombinant rat calretinin: Similarity to native rat calretinin. Protein Expr. Purif. 5, 187191.

26. Maruyama, K., Mikawa, T. \& Ebashi, S. (1984) Detection of calcium binding proteins by ${ }^{45} \mathrm{Ca}$ autoradiography on nitrocellulose membrane after sodium dodecyl sulfate gel elektrophoresis. $J$. Biochem. 95, 511-519.

27. Veenstra, T.D., Gross, M.D., Hunziker, W. \& Kumar, R. (1995) Identification of metal-binding sites in rat brain calcium-binding protein. J. Biol. Chem. 270, 30353-30358.

28. Aquaron, R.R. \& Wang, C.L. (1980) Binding of $\mathrm{Ca}^{2+}$ and $\mathrm{Tb}^{3+}$ to calmodulin. Ann. N. Y. Acad. Sci. 356, 354-355.

29. Wang, C.L., Leavis, P.C., Horrocks, W.D., Jr. \& Gergely, J. (1981) Binding of lanthanide ions to troponin C. Biochemistry 20, 2439-2444.

30. Ma, C. \& Opella, S.J. (2000) Lanthanide ions bind specifically to an added "EF-Hand" and orient a membrane protein in micelles for solution NMR spectroscopy. J. Magn. Reson. 146, 381-384. 